\author{
Magdalena PioruneK \\ Uniwersytet im. Adama Mickiewicza \\ $w$ Poznaniu
}

\title{
ZAUFANIE INTERPERSONALNE JAKO KOMPONENT RELACJI EDUKACYJNYCH I POMOCOWYCH
}

\begin{abstract}
Aвstract. Piorunek Magdalena, Zaufanie interpersonalne jako komponent relacji edukacyjnych i pomocowych [Interpersonal Trust as a Component of Educational and Helping Relationships]. Studia Edukacyjne nr 49, 2018, Poznań 2018, pp. 41-53. Adam Mickiewicz University Press. ISSN 1233-6688. DOI: $10.14746 /$ se.2018.49.3
\end{abstract}

The category of trust has been considered in numerous philosophical, sociological, psychological, economic, legal, and educational deliberations. The issue of whether trust occurs in or is absent from human relationships has been widely discussed in the social discourse and has been a component of social capital of organisations.

This paper reviews interdisciplinary literature to characterise and describe the phenomenon, identifying its dimensions, types, and patterns. It focuses on interpersonal trust as a factor characterising the functioning in organisations, also with reference to educational institutions. The author also identifies trust in the context of helping relationships in which it is a component of the contract-forming process between those who provide and those who use help, of establishing and developing relationships.

Key words: trust, educational relationships, helping and therapeutic relationships, culture of trust

\section{O zaufaniu jako podstawie relacji społecznych - rozważania propedeutyczne}

Każde działanie społeczne musi uwzględniać element nieznanej i niekontrolowalnej przyszłości, której ono dotyczy. Wiąże się zatem z ryzykiem zaangażowania się $\mathrm{w}$ określoną interakcję. Jednostka może poradzić sobie ze wspomnianym ryzykiem $\mathrm{w}$ trojaki sposób $\mathrm{b}^{1}$ :

- może żywić nadzieję, że sprawy potoczą się pomyślnie lub wręcz przeciwnie (często nieracjonalne przeczucie wiążące się z pasywnym oczekiwaniem na rezultat określonej interakcji; element dyskursu losu);

${ }^{1}$ Por. P. Sztompka, Zaufanie. Fundament społeczeństwa, Kraków 2007, s. 67-69. 
- mieć przekonanie co do pozytywnego lub negatywnego ich sfinalizowania (także nie towarzyszy mu aktywne zaangażowanie, choć przeświadczenie o efektach określonych interakcji może być bardziej uzasadnione, np. wcześniejszymi doświadczeniami jednostki; także składnik wspomnianego dyskursu losu);

- może zaufać (lub przeciwnie wykazać się nieufnością) w odniesieniu do nieprzewidywalnego rezultatu określonej interakcji; zaufanie lub jego brak ma charakter podmiotowego przewidywania efektów określonych działań.

"Zaufanie jest zakładem podejmowanym na temat niepewnych przyszłych działań innych ludzi"2. Ufając, wierzymy w dobrą wolę innych podmiotów interakcji, będąc nieufnym - przeciwnie, mamy negatywne oczekiwania wobec tych osób. Zaufać szczególnie trudno w chaotycznej, płynnej rzeczywistości nacechowanej zmiennością, nieprzewidywalnością, niepewnością, permanentnym ryzykiem. Zwłaszcza, że ryzyko jest immanentną cechą każdego aktu zaufania, a przymioty rzeczywistości społecznej ten obszar ryzyka jeszcze powiększają ${ }^{3}$.

Sztompka ${ }^{4}$ opisuje cztery odmiany zaufania wyrażane w działaniach człowieka. Są to zaufanie antycypujące (ufamy komuś, ale działania tej osoby są niezależne od naszej aktywności, a obdarzony zaufaniem nawet nie musi mieć takiej świadomości), zaufanie powiernicze (powierzenie komuś za jego zgodą wartościowej dla nas osoby, rzeczy np. dziecka opiekunce, nauczycielce, członka rodziny lekarzowi; powierzenie to może dotyczyć także nas samych, kiedy udajemy się do terapeuty, adwokata, lekarza), zaufanie obligujące, gdy wywołujemy wiarygodność partnera lub liczymy na jego wzajemność oraz zaufanie sprowokowane, kiedy celowo demonstrujemy naszą wiarygodność. Wszystkie rodzaje zaufania mogą się wzajemnie uzupełniać i być elementami pojedynczego aktu zaufania. Nasze zaufanie ma charakter "stopniowalny", a łączące się z nim zaangażowanie uwarunkowane jest rozmiarem konsekwencji związanych z udzieleniem tego zaufania, długością interakcji w którą wchodzimy, możliwością vs brakiem tejże, wycofania swojego zaufania oraz stopniem ryzyka i wielkością strat związanych z sytuacją, kiedy nasze zaufanie zostanie zawiedzione ${ }^{5}$.

Zaufanie związane jest zawsze z dokonywaniem wyboru i ponoszeniem ryzyka, które może mieć różną postać. Po pierwsze, wiąże się z możliwością przyszłych niekorzystnych zdarzeń, niezależnych od naszego zaufania, na przykład psycholog, do którego uczęszczamy na terapię, może bardzo dobrze lub źle ją prowadzić, niezależnie od zaufania, które w nim pokładam. Po wtó-

\footnotetext{
2 Tamże, s. 69-70.

3 Z. Bauman, Ptynne czasy, Warszawa 2007.

${ }^{4}$ P. Sztompka, Zaufanie. Fundament społeczeństwa, s. 74-78.

${ }^{5}$ Por. tamże, s. 79.
} 
re, ryzykujemy szereg negatywnych skutków psychologicznych będących efektem naszego rozczarowania, kiedy obdarzyliśmy zaufaniem osobę, która na to nie zasługiwała, szczególnie gdy druga strona jest tego kredytu zaufania świadoma i powinna w związku z tym czuć się zobowiązana aby go nie zawieść. Ryzyko dotyczy także zaufania powierniczego, kiedy powierzamy czyjeś pieczy cenne dla nas dobra, na przykład nauczycielowi swoje dziecko, a on zlekceważy wynikające z tego faktu zobowiązania.

Hardin $^{6}$ z kolei traktuje zaufanie jako kategorię kognitywną, stanowiącą rodzaj wiedzy, a to czy kogoś obdarzamy zaufaniem czy nie jest mniej lub bardziej świadomą strategią opartą na wiedzy. Nie darzymy zaufaniem, jak uważa, na przykład określonych organizacji, władz samorządowych, czy rządowych gdy niewiele wiemy o ich działalności.

Uslaner $^{7}$ wskazuje na dwa rodzaje zaufania. To oparte na wiedzy - z góry zakładające pewien stopień ryzyka - nazywa strategicznym, zaś ufundowane na systemie wartości jednostki - związane z wiarą, że inni podzielają nasze wartości moralne, wiążące nas ze wspólnotą i stanowiące podstawę rozwiązywania problemów dotyczących zbiorowości - to zaufanie normatywne. Zaufanie strategiczne obejmuje osoby, które znamy i umożliwia współpracę w określonej grupie współpracowników, zaufanie normatywne odnosi się zaś do ludzi w ogóle i wiąże z imperatywem ich pozytywnego traktowania, także wtedy gdy nie liczymy na wzajemność.

Zaufanie interpersonalne i społeczne (publiczne) według Sztompki nie różnią się znacząco. To pierwsze dotyczy konkretnych relacji z drugim człowiekiem, to drugie - rozszerza się na publiczne struktury, instytucje, organizacje.

...(...) na granicy między zaufaniem międzyosobowym a zaufaniem społecznym (czy publicznym) znajdują się kategorie społeczne (rozumiane jako zbiór ludzi podobnych do siebie pod względem jakiejś cechy), na przykład zaufanie czy nieufność mogą być adresowane do płci $(\ldots)$, wieku $(\ldots)$, rasy $(\ldots)$, pochodzenia etnicznego $(\ldots)$, religii $(\ldots)$, statusu materialnego (...) itd. (...) ta forma zaufania opiera się często na stereotypach i uprzedzeniach...9.

Kolejnym obiektem zaufania społecznego mogą być role społeczne osadzone w konkretnym kontekście społeczno-historycznym, związane z charakterystycznymi sposobami działania przewidzianymi dla danych pozycji społecznych (np. zaufanie do nauczycieli, prawników, lekarzy), czy grupy

\footnotetext{
${ }^{6}$ R. Hardin, Zaufanie, Warszawa 2009.

7 E.M. Uslaner, Zaufanie strategiczne i zaufanie normatywne, [w:] Socjologia codzienności, red. P. Sztompka, M. Bogunia-Borowska, Kraków 2008.

${ }^{8}$ P. Sztompka, Zaufanie. Fundament spoteczeństwa.

9 Tamże, s. 105.
} 
społecznej (np. zaufanie do młodszych dzieci, a jego brak w stosunku do gimnazjalistów) oraz procedury (np. egzaminu maturalnego) czy systemy (np. eksperckie, państwowe itd.). Zaufanie wiąże się zatem z dokonywaniem wyboru - zaufać lub tego nie robić.

Bazowe zaufanie nabywane we wczesnym dzieciństwie ${ }^{10}$ pełni ważną socjalizacyjną funkcję i umożliwia budowanie więzi międzyludzkich, zaś według Giddensa ${ }^{11}$ jego bezosobowy wymiar pojawia się w miarę dorastania jako relacja zapośredniczona, zgeneralizowany stosunek do grup społecznych, norm, systemów.

...Relacyjnym wymiarem zaufania zajmuje się teoria racjonalnego wyboru (...). Główne założenie tej teorii mówi, że zarówno osoby obdarzające zaufaniem, jak i nim obdarzone są racjonalnymi jednostkami dążącymi do maksymalizacji własnych „wypłat” (realizacji celów, osiągnięcia korzyści, wypracowania zysku, pomniejszenia kosztów) (...) Zaufanie postrzega się jako przejaw interesu... związanego z maksymalizacją zysku i minimalizacją strat w sytuacji ryzyka ${ }^{12}$.

Rolę zaufania w życiu społecznym, w nawiązywaniu i podtrzymywaniu relacji międzyludzkich, podkreślali na przestrzeni dziejów znani filozofowie. W pracach Arystotelesa, Machiavellego, Hobbesa, Locke'a można odnaleźć rozważania dotyczące skutków braku zaufania. Sokrates, Arystoteles, św. Tomasz z Akwinu odwoływali się do różnych wymiarów zaufania, z kolei Platon, Seneka wskazują na zagrożenia wynikające $z$ zaufania dogmatycznego ${ }^{13}$.

Zaufanie, zdaniem Sztompki, umożliwia efektywne funkcjonowanie i współdziałanie społeczne partnerów interakcji (gdy obdarzamy nim racjonalnie), mobilizuje podmiotowość jednostki, wyzwala jej aktywność i zaangażowanie, zwiększa otwartość $\mathrm{w}$ relacjach $\mathrm{z}$ innymi, przyczynia się do częstszego inicjowania interakcji, ich podtrzymywania i intensyfikowania. Ufność często łączy się z życzliwością, tolerancją, optymizmem, poczuciem sprawstwa. W kontekście wspólnot zaufanie społeczne przyczynia się do poszerzenia i wzbogacenia więzi międzyludzkich, przyczynia do zwiększenia społecznego kapitału jednostki, sprzyja komunikacji, tolerancji, akceptacji różnic, przyczynia się do wytworzenia solidarności zbiorowej, podejmowania działań na rzecz współpracy i dla dobra innych ${ }^{14}$.

Jeśli zaufanie rozpatrujemy jako relację, obdarzanie nim ma związek z oceną wiarygodności partnera interakcji. Ta zaś odbywa się na podstawie in-

${ }^{10}$ E.H. Erikson, Dzieciństwo i społeczeństwo, Poznań 1997.

11 A. Giddens, Konsekwencje nowoczesności, Kraków 2008; tenże, Nowoczesność i tożsamość, Warszawa 2018.

${ }^{12}$ P. Sztompka, Zaufanie. Fundament społeczeństwa, s. 135.

${ }_{13}$ M. Czajkowska, Zaufanie w organizacji - filozoficzny zarys podstaw zagadnienia, Acta Universitatis Lodziensis Folia Oeconomica, 2010, 234, s. 409-420.

${ }^{14}$ P. Sztompka, Zaufanie. Fundament społeczeństwa. 
formacji i wiedzy (prawdziwej, kompletnej vs nieprawdziwej, wyrywkowej) na temat tego partnera. Z kolei, jeśli zaufanie odnosimy do cech osobowości jednostki i traktujemy je jako skłonność psychologiczną, ocena wiarygodności partnera odbywa się raczej na podstawie doświadczeń biograficznych i przebytego treningu socjalizacyjnego, jaki stał się udziałem osoby zamierzającej kogoś obdarzyć zaufaniem (brak bazowej ufności ukształtowanej w dzieciństwie, negatywne doświadczenia związane z obdarzaniem innych zaufaniem $w$ rodzinie, specyficzne doznania socjalizacji wtórnej). Niebagatelne znaczenie ma też wzrastanie $\mathrm{w}$ kulturze zaufania $v s$ nieufności, która wywiera na jednostkę nacisk w kierunku obdarzania zaufaniem lub jego wycofywania w stosunku do określonych obiektów, niezależnie od oceny wiarygodności partnera czy skłonności osobowościowych podmiotu ${ }^{15}$.

Osoby wywiązujące się z udzielonego zaufania postrzega się jako wiarygodne. Ustalenie owej wiarygodności nie jest zadaniem łatwym. Możemy o niej wnioskować pośrednio, na podstawie obietnic partnera interakcji, projekcji interesu, który on potencjalnie ma $\mathrm{w}$ wywiązaniu się $\mathrm{z}$ obietnicy, jego charakteru, czy podejmowanej przez niego roli. Możemy również wiarygodność tę stwierdzać bardziej bezpośrednio (co samo w sobie nie eliminuje ryzyka obdarzania kogoś zaufaniem), na przykład poprzez reputację potencjalnego partnera interakcji, jego faktyczne osiągnięcia i prezentację $\mathrm{w}$ działaniu czy wizerunek. Każdy z tych elementów może podlegać manipulacji, a koncepcja Goffmana ${ }^{16}$ dobrze opisuje możliwości wykorzystywania różnych atrybutów, aranżowania scen i odgrywania scenariuszy ról w "teatrze życia codziennego", których zadaniem jest właśnie przekonanie partnera interakcji o swojej wiarygodności. Posiadana wiarygodność daje jednostce wewnętrzną satysfakcję związaną z poczuciem uznania, akceptacji, znaczną swobodę działania przy zmniejszonej kontroli, stanowi przepustkę do kolejnych sieci wsparcia i wpływów, jest elementem samooceny i składnikiem tożsamości jednostkowej.

Zawsze jednak ufając ryzykujemy, ponieważ niezwykle trudno oszacować prawdopodobieństwo, na przykład dotrzymania umowy przez osobę, którą tym zaufaniem obdarzamy.

(...) Zaufanie oparte na wierze w wiarygodność osoby, której ufamy, jest bardziej narażone na klęskę i ryzyko niż zaufanie oparte na wiedzy o osobie, której chcemy zaufać. A więc racjonalizacja i demistyfikacja zaufania może przynajmniej częściowo ryzyko z nim związane wyeliminować ${ }^{17}$.

${ }^{15}$ Por. P. Sztompka, Zaufanie. Fundament spoteczeństwa, s. 151-153.

${ }^{16}$ E. Goffman, Człowiek w teatrze życia codziennego, Warszawa 2011.

17 A. Drabiarek, Zaufanie jako podstawowa wartość przestrzeni publicznej w wymiarze lokalnym, Studies in Global Ethics and Global Education, 2014, 2, s. 8. 
W kontekście działalności organizacji zaufanie możemy traktować jako składnik i wynik procesów interakcyjnych lub odnieść je do spostrzegania oraz oceny cech osoby obdarzanej zaufaniem ${ }^{18}$. Pierwsze $\mathrm{z}$ wymienionych podejść opiera się na teorii wymiany społecznej i odwołuje do następujących założeń: wzajemności tej wymiany, jej długoterminowości, diadyczności (wymiana odbywa się między dwoma podmiotami) i racjonalności odwołującej się do maksymalizacji korzyści.

...Drugie podejście koncentruje się na subiektywnie spostrzeganym potencjale osoby do wywiązywania się z podjętych zobowiązań na podstawie jej cech i właściwości. $\mathrm{W}$ obu podejściach zaufanie nie jest obiektywnie istniejącym, ale dynamicznym $\mathrm{i}$ indywidualnie uwarunkowanym zjawiskiem występującym między osobami... ${ }^{19}$.

Mayer, Davis i Schoorman ${ }^{20} \mathrm{w}$ modelu wiarygodności w organizacji wskazują na trzy czynniki stanowiące podstawę jej budowania: zdolność (kompetencje potwierdzone $\mathrm{w}$ działaniu), życzliwość (stopień, w jaki obdarzany zaufaniem dba o dobro partnera interakcji, niezależnie od personalnych korzyści) oraz spójność (zgodność czynów z deklaracjami, dotrzymywanie obietnic, uczciwość).

Zaufanie w organizacji jest bazą rozwoju kultury empowermentu (upełnomocnienia), związanego z poczuciem kompetencji, możliwości decydowania o sobie, poczucia sprawstwa, co prowadzi do autonomicznego współdziałania zespołów pracowniczych ${ }^{21}$.

Dla powstawania wspólnot i budowania społeczeństwa obywatelskiego szczególnie istotne są, według Sztomki²2 zaufanie, lojalność i solidarność, a ich przeciwieństwa - cynizm, manipulację i obojętność Autor wskazuje jako podstawy amoralnych relacji międzyludzkich. Zaufanie według Putnama ${ }^{23}$ łączy takie wartości instrumentalne, jak lojalność oraz solidarność i odgrywa znaczącą rolę w budowaniu społecznego kapitału grupy.

18 A. Jaklik, M. Łaguna, Zaufanie w organizacji. Analiza sposobów ujęcia i modeli teoretycznych, Psychologia Społeczna, 2015, 4, s. 370.

19 Tamże, s. 370.

${ }^{20}$ R.C. Mayer, J.H. Davis, D. Schoorman, An integrative model of organizational trust, Academy of Management Review, 1995, 3, s. 709-734.

${ }^{21}$ M. Czajkowska, Zaufanie w organizacji - filozoficzny zarys podstaw zagadnienia, Acta Universitatis Lodziensis Folia Oeconomica, 2010, 234, s. 409-420.

${ }^{22}$ P. Sztompka, O potrzebie wspólnoty obywatelskiej, „Dziennik”, 5.listopada 2007, http:// wiadomosci.dziennik.pl/wydarzenia/artykuly/175401,o-potrzebie-wspolnoty-obywatelskiej. html, [dostęp: 23.08.2018].

${ }_{23}$ R.D. Putnam, Demokracja w działaniu. Tradycje obywatelskie we wspótczesnych Włoszech, Kraków 1995; tenże, Samotna gra w kręgle. Upadek i odrodzenie wspólnot lokalnych w Stanach Zjednoczonych, Warszawa 2008. 


\section{Zaufanie w relacjach edukacyjnych}

Zaufanie pomiędzy poszczególnymi podmiotami edukacji (uczniowie, rodzice, nauczyciele, pozostali pracownicy szkoły, jednostki nadzoru edukacyjnego i bezpośredniego kontekstu funkcjonowania szkoły) jest jedną ze składowych kultury szkoły. Czerepaniak-Walczak ${ }^{24}$ wskazuje na możliwość wyróżnienia dwóch typów kultury szkoły z uwzględnieniem fenomenu zaufania: kultury zaufania paternalistycznego i krytycznego.

Pierwszy typ kultury szkoły cechuje zaufanie interpersonalne bazujące na magicznym lub naiwnym zawierzeniu tym, którzy sprawują władzę, uznawaniu formalnych symboli oraz praktyk społecznych i edukacyjnych, a także poleganiu na normach ustalonych odgórnie. Przejawia się to w idolatrii oraz uznaniu moralnego i intelektualnego zwierzchnictwa tych, którzy dysponują siłą oraz tworzą ramy doświadczeń uczestników życia szkolnego. Natomiast kulturę krytycznego zaufania cechuje rozumienie i emocjonalne zaangażowanie podmiotów oraz zdawanie sobie przez nich sprawy z własnej mocy sprawczej, możliwości dokonywania wyborów i gotowości do ponoszenia odpowiedzialności. Ten typ kultury szkoły funkcjonuje w efekcie negocjowania znaczeń, uzgadniania celów i dróg ich osiągania ${ }^{25}$.

Szkoła w różnym stopniu może stać się przestrzenią praktykowania zaufania i społecznego zaangażowania poszczególnych podmiotów edukacyjnych, w tym uczniów, dla których jest ona miejscem budowania kapitału społecznego (co wielowymiarowo pokazują m.in. badania Dudzikowej z zespołem $^{26}$ ). Ten z kolei stanowi jeden z elementów budowania kapitału kariery, tak istotnego $\mathrm{w}$ funkcjonowaniu na rynku pracy. Zdziarski ${ }^{27}$ wskazuje na istotne normatywne elementy kultury zaufania w szkole, do których zalicza między innymi: efektywne relacje komunikacyjne pomiędzy podmiotami interakcji edukacyjnych, dobre samopoczucie uczniów w szkole, ocenianie szkolne oparte na przejrzystych zasadach i poczuciu sprawiedliwości, a ponadto klimat sprzyjający zaangażowaniu i ujawnianiu twórczego potencjału jednostek w kontekście poczucia sprawstwa. Według Kwiatkowskiej ${ }^{28}$, zaufanie jest kategorią miękką mającą wymiar międzyludzki, związaną z tworzeniem uczuciowego klimatu wychowania w szkole. Autorka ta wskazuje na

${ }^{24}$ M. Czerepaniak-Walczak, Kultura szkoły - o jej złożoności i wielowymiarowości, Pedagogika Społeczna, 2015, 3, s. 77-87.

${ }_{25}$ Tamże, s. 82.

${ }^{26}$ Por. np. M. Dudzikowa i in., Oblicza kapitału społecznego uniwersytetu. Diagnoza-interpretacje-konteksty, Kraków 2013; S. Jaskulska, Zaufanie i zaangażowanie jako wymiary szkolnego kapitatu społecznego. Doniesienie z badań, Studia Edukacyjne, 2012, 22, s. 169-178.

${ }^{27}$ K. Zdziarski, Normatywne elementy kultury zaufania w interakcjach nauczyciel-uczeń, Forum Oświatowe, 2011, 1(44), s. 77-101.

${ }^{28}$ H. Kwiatkowska, Zaufanie w przestrzeni komunikacyjnej szkoty, Studia Edukacyjne, 2012, 22, s. 109-126. 
wiarygodność jako podstawę zaufania w edukacji, przy czym definiuje ją jako kategorię do zdobycia, nie zaś wynikającą z nadania społecznego ${ }^{29}$. Wiąże zaufanie z udostępnianiem siebie innym, z otwartością na Innego. Nauczyciel zdobywa zaufanie uczniów i rodziców praktykując w szkolnej codzienności zasady demokratycznego współżycia w wymiarze efektywnej, podmiotowej komunikacji językowej, umiejętności rozwiązywania konfliktów z poszanowaniem racji i autonomii wszystkich stron, umiejętności taktownego reagowania na uczniowski opór, czy wzmacniania kultury dialogu i tolerancji.

Czerwiński ${ }^{30}$ dostrzega konieczność oraz możliwości kształtowania kultury zaufania i budowania prospołecznych więzi na poziomie edukacji akademickiej, wskazując, że u ich podłoża znajduje się właściwa komunikacja, sprawiedliwość, lojalność i dotrzymywanie umów w relacjach nauczycieli akademickich ze studentami, promowanie współpracy i partnerstwa w działalności badawczej.

Nie sposób nie dostrzec jednak, że budowanie owej kultury zaufania wymaga promowania wśród studentów zachowań związanych z uczciwością wobec samego siebie, wobec kadry nauczycielskiej, jak i pozostałych uczących się. Nie sprzyjają temu z pewnością nieuczciwe praktyki ściągania, plagiatowania, czy niesamodzielnego przygotowywania prac zaliczeniowych, dyplomowych. Niezwykle trudno precyzyjnie określać skalę tych zjawisk, tym niemniej jednak zapewne większość nauczycieli akademickich miała $\mathrm{z}$ takimi sytuacjami do czynienia. Rzecz jednak w tym, żeby przeciwdziałanie tym nieuczciwym praktykom nie sprowadzało się do zachowań kontrolno-restrykcyjnych, ale wiązało się także z wpajaniem norm i zasad etycznych.

W powyższych rozważaniach odniesiono zaufanie przede wszystkim do relacji uczeń - rodzic - nauczyciel. Nie można jednak zapominać, że to zaledwie część sieci interakcji edukacyjnych. Wszak, w szkole będziemy mieli także do czynienia z określoną grupą nauczycieli i osobami kierującymi tym gronem pedagogicznym, a zbadanie poziomu zaufania $w$ ramach tych relacji pracowniczych mogłoby przynieść interesujące rezultaty. W zależności od perspektywy, jaką przyjmuje grupa - ekskluzywnej czy inkluzywnej - lojalność i solidarność grupowa w pierwszym przypadku przede wszystkim spajają grupę i służą obronie jej interesów, w drugim zaś stają się źródłem dobra wspólnego. Klimczak ${ }^{31}$ rozważając problemy etyki zawodowej, wskazuje na dominację postaw związanych z dokonywaniem wyborów i podejmowaniem działań przede wszystkim z perspektywy własnego interesu bezpośrednio związanego z przynależnością do określonej grupy zawodowej.

${ }^{29}$ Tamże.

${ }^{30}$ K. Czerwiński, Prospołeczne więzi moralne a edukacja akademicka, [w:] In the Circle of Axiological Problems of Academic Education, red. U. Ostrowska, Bydgoszcz 2013.

${ }^{31}$ B. Klimczak, Etyka zawodowa - jak to działa? Ekonomia i Prawo, 2010, VI, s. 15-24. 
...To stanowi źródło dylematu dla tych członków grupy zawodowej, którzy reprezentują wysoką moralną intensywność, ale pozostają w mniejszości. W sytuacji, gdy zaufanie i interes społeczny są poważnie zagrożone, mogą stanąć wobec dylematu: ujawnić niekorzystną dla społeczeństwa praktykę zawodową czy odejść z zawodu... ${ }^{32}$.

Osobną kwestią będzie zaufanie organów oświatowych nadzorujących prace grona pedagogicznego oraz próba ustalenia proporcji między kontrolno-restrykcyjnym komponentem ich pracy a działaniami stymulującymi aktywność, sprzyjającymi zaangażowaniu nauczycieli, doradztwem metodycznym, ochroną prawną itd.

\section{Zaufanie w relacjach pomocowych i terapeutycznych}

Profesjonalną pomoc psychopedagogiczną

możemy określić jako zachowanie społeczne, działalność prospołeczną, która jest uwarunkowana motywacją empatyczno-autoteliczną i w której wykorzystuje się wiedzę (...) specjalistyczną, aby w interakcji z człowiekiem potrzebującym - często na zasadach współpracy - zmierzać do rozwiązania problemów życiowych osoby wspomaganej, do przezwyciężenia jej trudności, do zapobiegania zaburzeniom i usuwania $\mathrm{ich}^{33}$.

W modelach działań profilaktycznych, rehabilitacyjnych i terapeutycznych [także coachingowych, tutoringowych, mentoringowych - M.P.] zmierzamy do optymalizacji funkcjonowania jednostki i jej otoczenia oraz relacji między nimi. Z kolei, pomoc nieprofesjonalna, świadczona wielokrotnie bez głębszej świadomości pomagającego i jego zawodowego przygotowania, niejako intuicyjnie, stanowi pierwsze (lub wręcz jedyne) wsparcie, jakiego doświadcza potrzebujący w naturalnych grupach odniesienia.

Na kształt relacji pomocowej wpływa zarówno specyfika potrzeb i charakterystyka psychorozwojowa jednostki potrzebującej wsparcia oraz jej społecznego kontekstu (jak środowiska pochodzenia, relacje pozapomocowe, w których jednostka pozostaje równolegle itd.), jak też charakterystyka i społeczny kontekst pomagającego. Do spotkania wspomaganego (wspomaganych) i pomagającego (pomagających) dochodzi w określonym czasie i miejscu ich biograficznego doświadczania, co wyznacza swoiste ramy zachodzących interakcji.

Powszechnie wskazuje się, że adekwatne, efektywne i etyczne wsparcie społeczne powinno uwzględniać prawo osoby wspomaganej do decydowa-

32 Tamże.

${ }^{33}$ H. Sęk, Społeczno-kliniczne podstawy teoretyczne różnych form pomocy psychologicznej, [w:] Społeczna psychologia kliniczna, red. H. Sęk, Warszawa 1993, s. 368. 
nia/współdecydowania czy, od kogo, w jakich okolicznościach, w jakiej formie i jak długo trwającą pomoc chce ona otrzymywać, jak również uwzględniać podmiotowość i autonomię wspomaganego, ale także pomagającego.

Zachowania pomocowe powinny przede wszystkim być dostosowane do potrzeb wspomaganego, preferować reakcje podtrzymujące i rozumiejące, a pomagającego cechować empatia, zdolność spostrzegania społecznego i prospołeczna motywacja prowadząca do zaangażowania na rzecz innej osoby. Podstawą relacji pomocowej jest zaufanie interpersonalne, do powstawania którego przyczyniają się liczne zachowania pomagającego, a wśród nich:

- przejawianie autentycznego zainteresowania, troski i szacunku wobec wspomaganego;

- wykazywanie zdolności do zachowania własnej psychicznej odrębności w kontakcie ze wspomaganym, która umożliwia efektywne działanie niezależnie od dojmujących uczuć niepokoju, bezsensu, obaw;

- odznaczanie się zdolnością do zachowania swoistej symetrii w kontakcie z potrzebującym pomocy, któremu także przysługuje rzeczywiste przyzwolenie na odrębność;

- umiejętność jasnego, precyzyjnego komunikowania informacji i intencji w kontekście werbalnym i niewerbalnym;

- zdolność do elastyczności w zachowaniu w zależności od potrzeb wspomaganego ${ }^{34}$.

Niebagatelne znaczenie dla kształtu relacji pomocowej będą miały także przekonania społeczne i jednostkowe dotyczące poczucia odpowiedzialności, sprawstwa, potrzeby zaangażowania (proporcji wkładu motywacyjnego i aktywności własnej pomiędzy pomagającym a wspomaganym), stereotypy postrzegania osób, grup poszukujących wsparcia lub od niego się odżegnujących.

Swoistym gwarantem zaufania obcym osobom jest często rygorystyczny, sformalizowany kontrakt (umowa, porozumienie, zobowiązanie), który chroni w sensie prawnym przed nadużyciami zaufania i zabezpiecza interes obu stron lub - jak ma to miejsce w relacjach pomocowych i terapeutycznych - kontrakt o charakterze mniej sformalizowanym, mający jednak postać precyzyjnej umowy co do przedmiotu i warunków wzajemnych relacji.

W przypadku psychologów, terapeutów, coachów kontrakt staje się wymogiem procesu pomocowego, a jego głębszy sens psychologiczny zasadza się na konkretyzacji celów związanych z uaktywnieniem zasobów własnych klienta, wskazaniu koniecznych działań oraz wzajemnych zobowiązań. Kontrakt służy także weryfikacji (zwłaszcza nierealistycznych) oczekiwań wspomaganego i pomagającego, ma stwarzać możliwość niepodjęcia postępowania

${ }^{34}$ Tamże. 
pomocowego lub wycofania się z niego, na przykład w przypadku stwierdzenia przez pomagającego braku kompetencji niezbędnych do udzielania skutecznej pomocy lub w sytuacji braku czy utraty zaufania między stronami. Kontrakt powinien chronić wspomaganego pomocy przed podejmowaniem pracy w obszarach przez niego niezaakceptowanych, nad którymi nie jest on gotowy pracować. Zawieranie kontraktu jest procesem (nie musi on być wypracowywany na jednym spotkaniu), w trakcie którego osoba zgłaszająca się po pomoc powinna uświadomić sobie swoje oczekiwania i wzbudzić rzeczywistą gotowość związaną z zaangażowaniem w proces pomocowy. Podmiot relacji pomocowej winien być traktowany jako osoba autonomiczna, z pełnym prawem do podejmowania decyzji.

W przypadku jednak wielu grup osób potrzebujących pomocy właśnie zdolność do samodecydowania, ponoszenia odpowiedzialności i ich własne poczucie autonomii i sprawstwa ulegają osłabieniu, podobnie jak zdolność do określania własnych potrzeb i standardów. (...) Sama procedura doprowadzania do zawarcia kontraktu ma wobec nich znaczenie pomocowe, o ile jest w niej dotrzymywana zasada poszanowania autonomii, wyrażająca się w nienarzucaniu warunków kontraktu, ale we wspomaganiu podjęcia i sformułowania własnych sądów i decyzji. Wymaga to nie tylko otwartości na pytania czy zastrzeżenia zgłaszane przez taką osobę, ale wręcz zachęty do ich formułowania. Dzięki samemu zawarciu kontraktu w taki sposób autonomia klienta w pierwszej kolejności jest niejako odtwarzana, a następnie wzmacniana ${ }^{35}$.

Relacja pomocowa ulega w toku procesu pomocowego ewolucji, a jej względna niesymetryczność w początkowej fazie kontaktów wynika często z bezradności i braku samodzielności osoby zgłaszającej się po wsparcie, co implikuje początkową dominację pomagającego. Rozwój relacji pomagający - wspomagany prowadzić ma w konsekwencji do wycofywania się pomagającego z tych pozycji, wiąże się też często z przeformułowaniem zasad kontraktu, także w sytuacjach pojawiania się nowych problemów, które nie były przez wspomaganego dostrzeżone, nie miał on gotowości ich przepracowywania lub zostały przez niego świadomie pominięte z powodu niedostatecznego zaufania do pomagającego. Opór psychologiczny jest częstym elementem procesu zmiany, może zatem pojawić się u wspomaganego na różnych etapach procesu pomocowego, którego ostateczną weryfikację stanowią dopiero rzeczywista aktywność i działania wspomaganego, a elastyczność relacji pomocowej i redefiniowanie zasad kontraktu w zależności od potrzeb może sprzyjać zwiększeniu wzajemnego zaufania pomiędzy pomagającym i wspomaganym oraz podnosić efektywność świadczonej pomocy.

35 A. Kalbarczyk, Autonomia odbiorcy pomocy - zasada, cel czy warunek skutecznego pomagania? [w:] Spoteczne i jednostkowe konteksty pomocy, wsparcia społecznego i poradnictwa. Koncepcje - Dyskursy - Inspiracje, red. M. Piorunek, Poznań 2018. 
Sztompka ${ }^{36}$ i Giddens ${ }^{37}$ wskazują na znaczenie edukacji dla zaufania. Jest ono ważną kategorią relacji społecznych, także edukacyjnych i pomocowych, istotną $\mathrm{w}$ relacjach sformalizowanych i nieformalnych, jakże często niedocenianą, pomijaną, praktykowaną tylko na poziomie deklaratywnym. Edukacja dla zaufania winna dokonywać się zarówno w skali makrospołecznej, jak również mezo- i mikrospołecznej, w rodzinie (socjalizacja pierwotna), szkole oraz instytucjach, organizacjach, mediach w ramach socjalizacji wtórnej, w których jednostka może podnosić poziom kompetencji poznawczych i moralnych (te pierwsze warunkują poziom rozwoju moralnego), spotykać znaczących innych obdarzających zaufaniem i budujących swoją wiarygodność, doświadczać kultury zaufania sprzyjającej traktowaniu zaufania i wiarygodności jako wartości oraz norm regulujących postępowanie. Budowanie zaufania w relacjach interpersonalnych wymaga doświadczania go w rodzinnej, szkolnej, zawodowej codzienności. Żeby zaufać, musimy podjąć z tym związane ryzyko, ale mieć też świadomość, jakie korzyści daje funkcjonowanie $\mathrm{w}$ atmosferze wzajemnego zaufania. Niebagatelną rolę mają w tym względzie do odegrania pedagodzy na wszystkich etapach edukacji.

\section{BIBLIOGRAFIA}

Bauman Z., Ptynne czasy, Wydawnictwo Sic! Warszawa 2007.

Czajkowska M., Zaufanie w organizacji - filozoficzny zarys podstaw zagadnienia, Acta Universitatis Lodziensis Folia Oeconomica, 2010, 234.

Czerepaniak-Walczak M., Kultura szkoły - o jej złożoności i wielowymiarowości, Pedagogika Społeczna, 2015, 3.

Czerepaniak-Walczak M., Perzycka E. (red), Zaufanie w szkole w społeczeństwie sieciowym, Wydawnictwo ZAPOL Dmochowski, Sobczyk, Szczecin 2013.

Czerwiński K., Prospołeczne więzi moralne a edukacja akademicka, [w:] In the Circle of Axiological Problems of Academic Education, red. U. Ostrowska, Uniwersytet Kazimierza Wielkiego, Bydgoszcz 2013.

Drabiarek A., Zaufanie jako podstawowa wartość przestrzeni publicznej w wymiarze lokalnym, Studies in Global Ethics and Global Education, 2014, 2.

Dudzikowa M., Wawrzyniak-Beszterda R., Jaskulska S., Marciniak M., Bochno E., Bochno I., Knasiecka-Falbierska K., Oblicza kapitału społecznego uniwersytetu. Diagnoza-interpretacje-konteksty, Oficyna Wydawnicza Impuls, Kraków 2013.

Erikson E.H., Dzieciństwo i społeczeństwo, Dom Wydawniczy Rebis, Poznań 1997.

Giddens A., Konsekwencje nowoczesności, Wydawnictwo Uniwersytetu Jagiellońskiego, Kraków 2008.

Giddens A., Nowoczesność i tożsamość, Wydawnictwo Naukowe PWN, Warszawa 2018.

Goffman E., Człowiek w teatrze życia codziennego, Wydawnictwo Aletheia, Warszawa 2011.

\footnotetext{
${ }^{36}$ P. Sztompka, Zaufanie. Fundament społeczeństwa.

37 A. Giddens, Nowoczesność i tożsamość.
} 
Hardin R., Zaufanie, Wydawnictwo Sic!, Warszawa 2009.

Jaklik A., Łaguna M., Zaufanie w organizacji. Analiza sposobów ujęcia i modeli teoretycznych, Psychologia Społeczna, 2015, 4.

Jaskulska S., Zaufanie i zaangażowanie jako wymiary szkolnego kapitału społecznego. Doniesienie $z$ badań, Studia Edukacyjne, 2012, 22.

Kalbarczyk A., Autonomia odbiorcy pomocy - zasada, cel czy warunek skutecznego pomagania? [w:] Społeczne i jednostkowe konteksty pomocy, wsparcia społecznego i poradnictwa. Koncepcje - Dyskursy - Inspiracje, red. M. Piorunek, Wydawnictwo Naukowe UAM, Poznań 2018.

Klimczak B., Etyka zawodowa - jak to działa? Ekonomia i Prawo, 2010, VI.

Kwiatkowska H., Zaufanie w przestrzeni komunikacyjnej szkoty, Studia Edukacyjne, 2012, 22.

Mayer R.C., Davis J.H., Schoorman D., An integrative model of organizational trust, Academy of Management Review, 1995, 3.

Putnam R.D., Demokracja w działaniu. Tradycje obywatelskie we wspótczesnych Wtoszech, Wydawnictwo Znak, Kraków 1995.

Putnam R.D., Samotna gra w kręgle. Upadek i odrodzenie wspólnot lokalnych w Stanach Zjednoczonych, Wydawnictwa Akademickie i Profesjonalne, Warszawa 2008.

Sęk H., Społeczno-kliniczne podstawy teoretyczne różnych form pomocy psychologicznej, [w:] Społeczna psychologia kliniczna, red. H. Sęk, Państwowe Wydawnictwo Naukowe, Warszawa 1993.

Sztompka P., Zaufanie. Fundament społeczeństwa, Wydawnictwo Znak, Kraków 2007.

Sztompka P., O potrzebie wspólnoty obywatelskiej, "Dziennik”, 5.listopada 2007, http://wiadomosci.dziennik.pl/wydarzenia/artykuly/175401,o-potrzebie-wspolnoty-obywatelskiej.html, [dostęp: 23.08.2018].

Uslaner E.M., Zaufanie strategiczne i zaufanie normatywne, [w:] Socjologia codzienności, red. P. Sztompka, M. Bogunia-Borowska, Wydawnictwo Znak, Kraków 2008.

Zdziarski K., Normatywne elementy kultury zaufania w interakcjach nauczyciel-uczeń, Forum Oświatowe, 2011, 1(44). 